\title{
Religious Transformation Of Seni Dodod At Mekar Wangi Village South Banten
}

Yuliawan Kasmahidayat

Jurusan Pendidikan Seni Tari FPBS UPI

Jalan Dr. Setiabudi No. 229 Bandung

\begin{abstract}
Selama proses transformasi budaya ditemukan adanya persinggungan antara seni tradisi dengan seni modern di luar wilayah seni Dodod. Dewasa ini terbentuk Gubahan Seni Dodod yang berfungsi sebagai sarana upacara perkawinan dan khitanan. Proses enkulturasi dilakukan secara formal di sekolah dengan menerapkan Gubahan Seni Dodod sebagai materi pembelajaran seni budaya. Penerapan Seni Dodod dalam bentuk asli serta gubahannya merupakan pewarisan non formal yang dilakukan di sanggar Seni Dodod, kalangan remaja, dan warga desa. Pemaknaan religiusitas Seni Dodod terekspresikan dalam kehidupan masyarakat desa Mekar Wangi, didasarkan pada pemaknaan yang dilakukan oleh para pimpinan pondok pesantren. Pemaknaan didasarkan pada penjelasan, yang menerangkan, menampakkan, menyibak, serta merinci tujuh ayat Al-Qur'an, yang melahirkan pemaknaan pada keutuhan ragam gerak, kostum yang digunakan, syair pantun Lutung Kasarung, dan mantra atau do'a yang digunakan dalam Seni Dodod, serta Seni Dodod sebagai kebudayaan dan kesenian Islam. Tampaknya kedudukan Seni Dodod dewasa ini mengalami pergeseran yang semula sebagai sarana ritual pertanian, kini menjadi bagian penting dalam upacara perkawinan dan khitanan, namun tidak sampai menjadi seni yang sekular.
\end{abstract}

Kata Kunci: Transformasi religiusitas, seni dodod

\section{INTRODUCTION}

Banten Province is one of the provinces in Indonesia whose people are known to be highly loyal to the teachings of Islam, the religion they adhere to. Most of its areas have cultures which highly refer to the teachings of Islam. However, the people living at Mekar Wangi village, Saketi District, Pandeglang Regency, South Banten, has a culture which is inspired by the faith adhered to by their ancestors. The traditional belief put into practice by their ancestors was the realization of the fact that the relationship between a tradition and a culture was determined by the intensity of the concepts of works and religious. Such a belief is part of Sunda Wiwitan tradition, a belief which was adhered to by the ancestors of the people living in some areas of South Banten.

Dodod which is in existence at Mekar Wangi village, Saketi District, Pandeglang Regency, South Banten, is a ritual art which is predicted to be born in the sixteenth century, which integrates the performing elements and music which contain softness and beauty of the musical sound produced by what is known as angklung and dog-dog. The movements made by the dancers are 
dynamic, the costumes and make-up worn by the dancers, which are derived from the material nature, quiver the hearts of the performers (the dancers, the musicians, and the other people involved in its performance).

As a ritual art, Dodod is closely related to the belief which has been inherited as a tradition from their ancestors. Such a belief can be observed in many activities done by the people or from their daily behavior, including their artistic behavior. In relation to that, it is interesting to analyze more deeply the religious transformation discourse contained in a ritual art, in line with the process of cultural transformation which has led to the religious change of Dodod performed by the pre-modern, the modern community, and the postmodern communities.

Dodod was born and has developed as a means of agricultural rituals, include: (1) tatanen, a ritual performed when rice is planted; (2) ngalaksa, a ritual performed when the rice plant bears fruit; and (3) rasulan, a ritual performed when the rice is harvested and stored in the rice barn. Dodod can be classified as the art of the common people, which, since it was created, has been used as a means of ritual and whose specific movements have been acted by males; females have only performed its basic movements. The deep values it contains are based on Islam; therefore, it is interesting to analyze in this study. The deep understanding of aesthetics has been one of the phenomenon which is closely related to its position and form analyzed in this study. The aesthetics intended does not only refer to the forms of how it is performed but also refers to the whole human creativity in their culture. Such creativity creates languages which can be used to express the beauty contained in the form of Dodod employed as the object of this research.

Based on the phenomenon which has been taking place in the last fifteen years at Mekar Wangi village in particular, it has been found out that a shift in belief has taken place in modern and postmodern communities of Mekar Wangi. Such a shift has resulted in a change in life pattern of the local people's activities and daily behavior, including their artistic behavior. In relation to that, the discourse of the religious transformation contained in $\mathrm{Do}$ dod is interesting to deeply analyze, based on the discourse of change from the premodern community (pre-Islam) and the modern community and the postmodern community (Islam).

The depth of such a discourse of shift and change has resulted in the analysis of meaningfulness, which is the realizaztion of the cultural and aesthetic expressions of the community supporting Dodod. In the pre-modern community, it functioned as a means of communication between the community living in the country and the creatures other than human beings which were considered to play roles in accelerating cultural activities in particular. Then a shift and change took place which finally led to new compositions as the realization of aesthetic expressions which are full with the values of Islam. This phenomenon is observed in how the new compositions are presented and performed. It has not been entirely presented as an agricultural ritual only. It is such a phenomenon which inspired and encouraged the researcher to conduct a research entitled "Religious Transformation of Dodod Taking Place at Mekar Wangi Village, South Banten". 
Based on what has been described in the background above, three basic problems are formulated as follows and in particular, this study aims at:; 1) what ideology has been responsible for the religious transformation of Dodod taking place at Mekar Wangi village; 2) how the process of religious transformation and inheritance of Dodod has currently occurred and will occur at Mekar Wangi village; how the community elucidates the religious transformation of Dodod which is currently taking place and which will occur in the future at Mekar Wangi village?

\section{ANALYSIS}

Academically, this study 1) contributes and enriches the theoretical studies of the development of science, especially Cultural Studies and Arts; 2) serves as one of the references for encouraging further researches, in which religious approach, especially Islam, may be employed in researches of cultural studies; 3) serves as one of the references in researches in which religion, especially Islam, as the majority one adhered to by most people living in South Banten, is employed as the approach for analyzing the forms of the other arts both in Banten Province in particular and in the other parts of Indonesia in general.

In practice, this study is expected to be useful to the community to which Dodod belongs to, kaum ulama (Moslem leaders), religious organizations and other related organizations. 1) To the community to which it belongs to, this study at least gives insights into and views of the transformational process as an attempt made to inherit arts and culture among the peo- ple for whom religious functions as the binding characteristic; 2) to the Moslem leaders and the leaders of Moslem boarding school (pondok pesantren), the findings of this study may serve as input for broadening the insights into and views of the existence and position of the religious transformation of Dodod, which is part of every religious ritual performed by the people living at Mekar Wangi village, South Banten; 3) it is expected that the results of this study are useful to the Indonesian governmental organizations, especially to the Indonesian Moslem leaders (Majelis Ulama Indonesia) and to the other related governmental organizations as far as the religious meaningfulness of Dodod which is based on the values of Islam is concerned.

Based on the library research already conducted, no foreign researcher has deeply conducted any research in Dodod. The only researcher who conducted a research directly related to it in 2002 but with the anthropological prospective. It revealed how the farming community went through the cycle of life starting from when they were born, how they lived to when they died as reflected in the agricultural process done. The Rasulan ritual refers to the ritual performed when rice is already stored in what is termed as leuit (the barn where rice is stored) and to respect Sang Hyang Dewi Sri (the Goddess of Rice) for the rice abundantly harvested.

The findings of that research are highly helpful to the current study. It prepares the initial data needed for developing the analysis of the ethnography of Mekar Wangi village and for identifying the problems formulated, that is, the meaningfulness given by the community towards the religious transformation of Dodod which 
was born and developing during the era when the ancestors of the people living in that village lived. To make the analysis easier, the people to which Dodod belongs to are divided into two groups. The first group belongs to the past or pre-Islam community and the second group belongs to the modern or postmodern or Islam community.

In line with the change in regard to the thinking pattern of the people living at Mekar Wangi village to whom Dodod belongs to, its new compositions and packages have been found out. Its traditional function is still maintained by several groups of people as what is termed as nadzar, which refers to an individual or collective intention to perform an art when they finish harvesting their rice. Its new function, which is expressed by its new compositions or packages, has been created based on Moslem philosophy. In other words, its content refers to Islam.

The phenomenon mentioned above is analyzed in this dissertation, that is, the process of the religious transformation and inheritance of Dodod. The perception of kaum ulama (the Moslem leaders) and the leaders of pondok pesantren (Moslem boarding schools) of the depth of its religious meaning is also revealed in this study. Finally, it is hoped that the characteristics of the religious people living at the village where the research was conducted will lead to a new theoretical formulation which reveals the new horizon of cultural phenomenon based on the religiosity of Islam in South Banten.

In this study how cultural studies view the patterns of relationship between knowledge and power applied by the $\mathrm{Ki}$ yai (Moslem leaders) to the meaningfulness of the religious values of Dodod can be observed. They put knowledge and power into practice in the form of network and widely spread them. It is in this matter Foucault applies the archeological and genealogical principles to exposing the meaningfulness of the religious transformation of Dodod which has been considered true so far. While archeology emphasizes the historical condition available as a slice of discursive network, genealogy highlights historical process as a network of discourse.

The research findings which are directly and indirectly relevant and contribute this current study are employed for deepening the analysis. Some revealed several indicators pertaining to the identity of the Banten community (Iskandar, 2001). The history of Banten or the manuscript of Banten starting from the $17^{\text {th }}$ century to the $19^{\text {th }}$ century was written in Pegon and Carakan characters, which was obtained by collecting several collections made by Snouck Hurgronje, Brandes and Rinkes and was completed with several individual collections before being composed into 11 manuscripts. Being concerned with the languages and literatures of the archipelago, his dissertation was written in the form of tembang (Javanese poems which are sung and recited). The type of the tembang employed was known as macapat (six-line Javanese verse form) in the strophes of Dudukwuluh for Magatruh, Lambangsari or Lambang for Kinanti, and Carangwreksa for Pangkur. The historical manuscript or the manuscript of Banten analyzed was literary work in the form of poems.

The literary work in the form of poems as mentioned above is highly helpful to this current study especially in interpreting the pantun (traditional poem) of Lutung Kasarung which is considered sacred by 
the people living at Mekar Sari village. Generally, to the Sundanese people, the poem of Lutung Kasarung is identical to literary work in the form of poems which contain religious values reflecting the essence of life of the people living in South Banten.

The review of the research findings obtained by Hoesein is highly useful and is employed as the reference for analyzing the historical background of the cultural phenomenon discussed in this dissertation, especially for explaining the positions of the forms of performing arts when they were initially employed by the Wali (religious leaders) as a means for spreading Islam and welcoming the great guests visiting Banten. The review of his research findings were also used for analyzing the depth of the meaning and the simbol Dodod contains based on what is interpreted by the Moslem community.

The study conducted by Hasbullah (2001) entitled Islam dan Transformasi Kebudayaan Melayu Riau (Integrasi Islam dalam Kebudayaan Melayu di Siak Sri Indrapura Propinsi Riau) is also referred to for analyzing the transformational process, that is, the cultural acculturation which takes place as a cultural contact or a concept of how a foreign culture is renewed by traditional or local culture. What foreign elements are accepted is determined by many factors. The permanent factor is that the values of the elements performed will be firstly observed from those which are seen. A community can only 'catch' the aspects which can be directly and clearly communicated. The new elements are accepted based on two types of quality; they are their usefulness and suitability. In other words, the new elements are accepted based on 'to what extent they benefit the community accepting them' and 'how easily they are adjusted to the culture already in existence'.

Such analysis is also relevant to the phenomenon found in the location where the current study was conducted, in which the religiosity of Dodod, as one cultural realization in South Banten, has also been influenced by foreign culture. The shift in perception of the position of form and how it is performed has resulted from many factors which are related to usefulness and suitability so that it still exists in the middle of the community supporting it.

Muhammad (2004) also conducted a research entitled Dari Teori ke Ideolo$g i$ which is also relevant to this current study. Therefore, it is also referred to as the basis for exposing the ideological basis used starting from when religiosity, transformation and enculturation of such a communal art took place in South Banten. Ideology, as a belief or a norm, refers to an element which highly influences human life both as individuals and community members. It is used as a reference when someone does something; meaning that when he/she does something, he/she almost always takes it into consideration based on the belief adhered to. Before he/ she does something, as a religious human being, for example, he/she will certainly evaluate whether what he/she does is in accordance with his/her religion or not. If it is, he/she will do it as well as possible, as he/she believes that what is done does not only affect his/her current life but also his/her heavenly life. However, if it contrasts with his/her belief, it is highly possible that he/she will not do it. Although, for one thing or another, he/she does it, he/ she will certainly feel faulty and sinful.

The religious position and existence 
of Dodod from 1994 to 2009 are diachronically analyzed. How it was performed in its various supporting realizations and the nature of its performance were observed. To this end, the several aspects it contains were observed. Such aspects include the volume of movements, the design or the lines resulting from the many movements and poses made by the physical parts of the performers when performing it and the property used.

There are two concepts used in this study; they are religious transformation and Dodod. Religious transformation is based on the religion closely related to the belief adhered to by a traditional community. Therefore, the analysis of religious transformation is classified as an interdisciplinary research, in which the interpretation of what Dodod contains cannot be separated from the meaningfulness created based on what is scientifically required by Al-Qur'an. The religious transformation highlighted in this study may mean a process of shift and change in meaningfulness of the religious values adhered to by the pre-modern community which influences how Seni Dodod is entirely performed. Its current forms newly performed as new compositions are based on the meaningfulness created as a collective agreement between the Moslem leaders (Kiyai) and all the performers, which is considered to contain Islam nuance.

Dodod is an art which is in existence and developing at Mekar Wangi village, Saketi District, Pandeglang Regency, South Banten. Its existence is closely related to the rituals performed when rice is planted, harvested and stored in what is termed as leuit (the rice barn). In its intact performance, it integrates art of movements and music; its performing movements are simply combined and are accompanied by musical rhythm produced by a set of musical instruments made up of angklung bambu (musical instrument consisting of suspended bamboo tubes which sound when shaken) and dogdog (one faced drum).

As a means of ritual, the performance of Dodod is related to particular requirements; they are (1) when and why it is performed; (2) what character or story is performed;' (3) what setting is used; and (4) who should be involved in it. The rituals in which Dodod is used are tetanen, ngalak$s a$ and rasulan. Its position in such rituals expresses the concepts of the people living in the country of various things related to their religious rituals. Those can be observed from (1) the meaning of the story performed, that is, the traditional poem of Lutung Kasarung containing the simbolic meaning of worldly and heavenly welfare; (2) the words, prayers and the physical movements or the gestures made by those supporting it express the simbolic behavior consolidating or restoring the nature and placing human beings and what they do in the natural order.

Five theories are employed in this study. They are: the theory of semiotics, the theory of hermeneutics, the theory of deconstruction, the theory of religious transformation, and the theory of power and knowledge. The theory of semiotics is used for explaining the practices of indication of the values Dodod contains, as part of the way of life of the people living in South Banten. This theory is also used for understanding comprehensively the aesthetics Dodod contains obtained through two approaches such as textual and contextual approaches. While the textual approach is applied by analyzing the signs, codes and meanings its performing text contains 
such as the movements, the costumes/ make-up worn and what accompanies its performance, the contextual approach is applied by analyzing the relationships of the signs, the codes and the meanings of such an art to the community possessing and supporting it.

The theory of hermeneutics employed in this study is based on Moslem hermeneutics, that is, that which is based on the interpretation or meaningfulness implied in the text. The norms employed and how to apply them are different from the interpretation commonly made. The interpretation made is formal in nature. The recording is based on what is termed as pen-ta'wil-an which is derived from the word awwal, meaning the first, a term which is also used to refer to the Creator. As the First (al-awwal), God is the place where all his creations return. Based on this, then the recording based on $t a^{\prime}$ wil is meant to mean 'returning or causing us to return (to the first or to what everything comes from) and meeting something which may not be lessened, that is, the meaningful or the last essence'.

Analyzing the characteristics of the people living in South Banten means discussing the essence of human life in accordance with religion (Islam in particular), based on further insights done by observing the attitude and behavior of the religious people. Dodod means dadasar (something which is basic/true) meaning the beginning and the end. The initial ritual when planting rice is tetanen, which is then followed by ngalaksa. Rasulan is the ritual performed in the final stage, that is, when rice is harvested. In the transformational process, the Moslem leaders (Kiyai) and the leaders of pondok pesantren (Moslem boarding school) has created the meanings of the aspects Dodod contains. This means that they have directly and indirectly applied hegemony in such a way that a new composition has been created.

Deconstruction is done by paying attention to various hidden phenomena or everything which has been hidden in Dodod. To make the depth of meaning not postponed, meaningfulness should be repeated and recreated. Meaningfulness will always change in accordance with contextual change. Meaning is searched for by deconstruction as a continuous process. Deconstruction will lead to everything to which no attention has been paid. Therefore, the deconstruction of the religious values of Dodod especially that done by the Moslem leaders (Kiyai) is a process during which awareness of social existence has been created. Derrida claims that in fact human life is always faced with various forms of power which is always in the dominating position. Logocentrism, as stated by Derrida, refers to the pressure over the existence of a community.

The theory of religious transformation refers to the phenomenon which emphasizes how radical the development of Dodod is; however, the creative process of religious transformation cannot be separated from the religious values adhered to by the pre-modern community. Therefore, the discourse of religious transformation should be viewed as a set of potentials previously provided and at the same time as the transformation of such potentials. The factors which are considered to lead to the transformational process as far as Seni Dodod is concerned are that 1) the topic and genre of the texts (movements, costumes) are renewed; 2) traditional art and what appears in most of the new cultures are compiled; 3) aggregation, which refers to 
a process of classification in which one form is classified into the form in which one character has equal relation to the culture into which it is classified; 4) change in scale and function, which refers to a condition which is relatively in existence in the form of the creativity of those performing Dodod, leading to the change in the length of time during which it is performed and in the function which intentionally and unintentionally shifts history; 5) the comparative meaningfulness created by the Moslem leaders (Kiyai) is one of the factors which has been responsible for the cultural change taking place by comparing one form to another form through what is stated by the leaders and the behavior of the community supporting it. This has been leading to the creation of new compositions of Dodod as the answer to the coherent challenge of the era.

The theory of power and knowledge is employed for analyzing the meaningfulness created by the Moslem leaders (Kiyai) for Dodod religiosity, meaning that a discourse has taken place. Discourse refers to all the activities done for meaningfulness whose essence rests on the human interaction or the dialogue of power in daily practices. An episteme contains various structures of discourse in the form of a cycle and has authority on a particular historical point (Mills, 2007: 77). Foucault employs the concept of episteme (system) for determining, observing and understanding a fact. Then, through reasoning and episteme, we can organize and control our knowledge of a fact. In episteme, it is stated how language is particularly related to a fact (F.R. Ankermit, 1987: 309 315). In relation to that, Foucault reminds that when a discourse is created, actually it is already controlled, selected, organized and redistributed in accordance with what is intended by that creating it.

The research model developed is as described below.

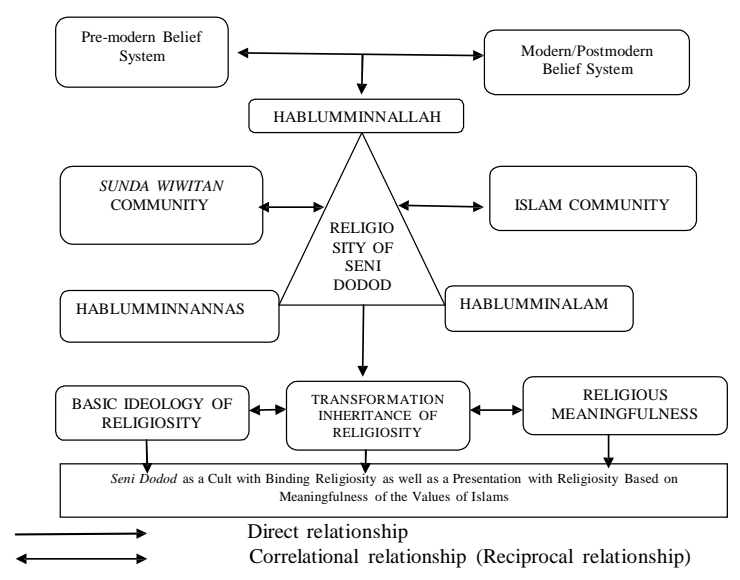

The target of this study is to find out and analyze qualitatively the religious

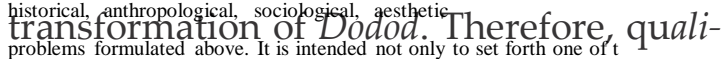
thatid eripa xadiogny employed in this study. It is multidisciplinary in nature with the Regency, South Banten, Banten Province. This village was decided to be the location where

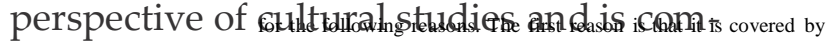

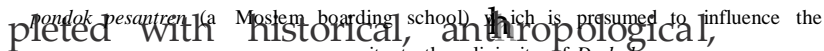

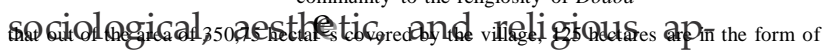
proaches to answer the problems formulated above. It is intended not only to set

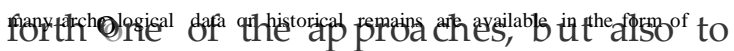
cover various aspects employed.

The research was conducted at Mekar Wangi village, Saketi District, Pandeglang Regency, South Banten, Banten Province. This village was decided to be the location where the research was conducted for the following reasons. The first reason is that it is covered by a pondok pesantren (a Moslem boarding school) which is presumed to influence the meaningfulness provided by the community to the religiosity of Dodod; the second reason is that out of the area of 350,75 hectares covered by the village, 125 hectares are in the form of agricultural area and that $70 \%$ of the villagers are farmers. 
Such natural condition is used as the initial data for analyzing the discourse of the characteristics of Dodod, in which Dewi Padi (the Goddess of Rice) is referred to as the cult; the next, which is the third reason, is that many archeological data on historical remains are available in the form of books entitled Benda Cagar Budaya (BCB) and Situs Kepurbakalaan Provinsi Banten. Such archeological data are referred to as the basic insights of the ancestors of the people living at Mekar Wangi village into the religious meaningfulness of the arts in existence in South Banten.

The data employed in this study were qualitative data which could be obtained by observing the position of Dodod in the community where it is performed. The data sources are divided into two:; primary data and secondary data. The primary data were obtained from (1) the informants who were the performers and the artists of Dodod and the leaders of pondok pesantren (Moslem boarding school); the primary data were collected through observation, active participation and in-depth interview; (2) several events such as rituals and Dodod performances including the performances of its new compositions; collected through observation; (3) the places or locations where it was performed. In addition, the secondary data were also used which were collected through the results of documentary analysis, files, mass media recording, relevant research findings, documentary pictures, and the other documents related to the problems formulated above.

The informants are Eni Surani (54 years of age) who is a performer, an artist and the last heir of Seni Dodod, and 8 (eight) of the 21 (twenty one) of the leaders of pondok pesantren at Saketi District. The 8 leaders of pondok pesantren (Moslem boarding school) were selected based on the form used as the research instrument returned and their preparedness to be directly interviewed by the researcher. When interviewing them, the researcher was accompanied by the last heir of Dodod. Many attempts were made to obtain the data through the interview which sometimes led to arguments with the leaders of pondok pesantren. However, with persuasive approach I could convince them that the meaningfulness of the level of religiosity of Dodod was explored based on the perspective of cultural studies. The supporting informants were the dancers and the musicians, the village leaders (head of Mekar Wangi village), the religious leaders both living at the location where the research was conducted and at the other locations which were assumed to be able to help the researcher analyze and identify the problems formulated in this study.

To reveal the information on religious transformation of Dodod, transformation and inheritance as well as the meaningfulness provided by the community especially the Moslem leaders to the position and religious content of the performing art and music as deeply as possible at the location where the research was conducted, the researcher also served as the instrument completed with systematically made interview guide. For the interview, a tape recorder, a cassette, a handycam, and field note taking were also employed. Note taking was needed for classifying the data obtained when the interview was performed in the field.

The techniques employed for collecting the data needed in this study were note taking based on participatory observation, and in-depth interview. Observation participatory was done by involving in many 
activities related to the performance of $\mathrm{Do}$ dod. To this end, the researcher stayed at the location where the research was conducted and continuously observed within a period of two years (2007-2009), without influencing the phenomenon observed. The researcher observed the performance of Dodod several times performed as a means of rituals of tetanen, ngalaksa, and rasulan at Mekar Wangi village. Its performance as new compositions in many events was directly observed at the city center of Pandeglang Regency, where arts festival was performed once a year to celebrate the anniversary of Pandeglang City. Direct observation was also done by the researcher to see the learning process of arts and culture at Mekar Wangi 1 Primary School for three months. This was done in order to obtain the information on Dodod which was inherited among the pupils as the generation continuing it at this village. Direct observation was also done when it was performed for wedding and khitanan (feast celebrating a circumcision) ceremonies to see how the cultural transformation of Dodod took place nowadays.

In order to gain in-depth analysis in this research, the writer processes all interview results of key interviewees and other supportive interviewees, direct and indirect observation of Dodod presentation in various events, and collected documents. Data reduction (categorization and abstraction) is the first phase which is executed by the writer to gain relevant and irrelevant data classification. Data collection is executed continuously from the beginning to the end of the research descriptively, qualitatively, and interpretatively. The technique which is used is the spiral circle technique, with the assumption that the writer will not be away from the problems. Broad in- sight and knowledge about the problems will give deeper understanding about the problems.

\section{Ideology which Background Dodod Reli- gious Transformation of Ancient Society of Mekar Wangi Village}

Dodod in Mekar Wangi village basically is a traditional cultural heritage of Banten ethnic group which was, at first, based on the basic ideology, namely the cult of Goddess of Paddy. The cult consists of ritual movements which are executed by performers of Dodod, especially in the past, which was still influenced by Sunda Wiwitan religion. The ritual movements lead to a form of worship which, in certain phases, lead to a phase or condition of spirit possession as a sign that the performers are possessed by spirits which exist around the village. The interpretation of sign relation which is interpreted by the ancestors toward Dodod is still influenced by animism and dynamism beliefs. The cult, which is influenced by totemism, is also seen when the performer reaches the possession phase. Movements in form of ritual expressions through totality of movements of lele ngoser and tikukur ngadu reflect ritual movements of their ancestors. In its further development, when the local society begins to understand Islam, the life values enter Dodod so that this art can be performed in marriage and circumcision ceremonies.

The two basic ideological interactions, that is, as the cult and the presentation of the religious values above, were based on its position and role in the three rituals performed when rice is planted and when it is harvested. The three rituals are tetanen, 
a ritual which is performed when the rice seedling is planted in the rice fields; $n g a$ laksa, a ritual which is performed when the rice plant bears fruit, and rasulan, a ritual which is performed when the rice is harvested and stored in the rice barn termed as the leuit.

The rituals which are performed starting from when the rice seedling is planted up to when it is harvested by the people living at Mekar Village, South Banten, reflect the cultural pattern three which refers to the existence of human beings on earth starting from the Beginning, the Middle, and the Final. The initial stage refers to when human beings are born on earth. The middle stage refers to their existence when they undertake their lives, and the final stage refers to when they die.

The ideology on which Dodod performed when the rice is planted and harvested is based refers to the belief that everything is focused on Sang Hyang Dewi Sri (the Goddes of Rice). Several groups of people still undertake their lives based on the teachings contained in the poem of Lutung Kasarung which may lead them to both worldly and heavenly tranquility. The story contained in it is always related to the ceremonies performed for rice cultivation. The word pantun means rice. The song of Lutung Kasarung which is sung when the rituals of tetanen, ngalaksa and rasulan are performed is part of rice religion. The reason is that they are performed in the framework of observing the soul of the rice which is personified as Nyai, Nyi Pohaci or Danghyang Kusnawati, that is, Dewi Sri (the Goddess of Rice).

\section{The Current Religious Transformation and Inheritance of Dodod}

Within the period of 15 years, that is, from 1994 to 2009, several groups of people were still identified to perform rasulan ritual. The activities done in the tetanen and ngalaksa rituals were also done in the rasulan ritual. However, the length of time during which they were performed was relatively shorter compared to that during which the rasulan ritual was performed. The changes emphasized were also in the aspects of role and function, form and structure of performance and meaning Dodod contains.

Based on the research findings, the process of contact, as far as Dodod is concerned, was apparently observed to take place in the last three years, especially when the researcher were collecting and processing the data. The contact between the researcher and the Moslem leaders (Kiyai) took place when the researcher related the clauses in Al-Qur'an to the religious values of Dodod. The last heir of Seni Dodod, Mr. E. Surani, as the key informant, who was always involved when the data were collected and processed, was directly and indirectly present when the contact took place. The dialogues between the researcher and the leaders of pondok pesantren played important roles in opening the pattern of thinking of the key informant of the last heir of Dodod concerning its existence in the modern and postmodern communities.

During those last three years, the key informant and the researcher tried to create several compositions of Dodod performed in several events. The current pattern of thinking of the people has influenced the art work of Dodod in terms of its move- 
ments, make-up and the costumes worn, the pattern of the floor, the property and the instruments used. However, the sequence of the music accompanying it, that is, angklung Dodod used, has tended to follow its original pattern. Several works which can be classified as its new compositions are 1) the Composition of Kohkol Dodod (created in 2007), which is in the form of musical attraction played by 20 adult musicians; (2) the original Collaboration of Dodod (created in 2008), which is in the form of performing attraction and music played by 15 supporting adults and 12 supporting children; (3) SKDA (standing for Senam Kesenian Dodod Angklung, created in 2009), developed from the performing movements in Dodod which are collaborated with health gymnastic movements. In its attraction, it is performed by primary school and secondary school children.

\section{Transformation of the Current Religious Meaningfulness of Dodod}

The people living in South Banten are known to be loyal to the teachings of Islam. They do their best to reform their environment in line with the teachings of tauid (the oneness of God) implanted in Islam. Therefore, the attempts made to give religious meaningfulness to Dodod are the attempts made to direct it properly so that it will be in line with the principles, values and conceptions of Islam. The meaningfulness provided is based on the clauses in Al-Qur'an which are focused on: (1) intactness of movements; (2) the costumes worn; (3) the meaning of the poem of $\mathrm{Lu}$ tung Kasarung; (4) the meaning of the magic formula or prayers; and (5) Dodod as the art and culture of Islam.
The religious meaningfulness of the movement intactness in Dodod is based on QS.3 (Ali Imran): 191. The religious meaningfulness of the make-up and costumes worn by the performers are based on what is required in QS. 7 ( $\mathrm{Al} \mathrm{A}^{\prime}$ raaf): 26. The religious meaningfulness of the depth of Lutung Kasarung poem used in Dodod is based on the aesthetic conception and aesthetic discourse in the literature of Islam, as stated in QS.26 (Asy Syu'araa): 224-227. The religious meaningfulness of the magic formula and prayers in Dodod is based on the exploitation of misleading language and words, as stated in QS.31 (Lukman) : 6 . The religious meaningfulness of Dodod as the art and culture of Islam is based on the research instruments of item 1 and item 5 . The meaningfulness which is based on the holy clauses in Al-Qur'an has caused the religious level of Dodod to shift, from being performed for rituals related to agriculture to being performed for wedding and khitanan ceremonies.

There are three findings as far as this research is concerned. The first finding is that the people living at Mekar Wangi is a community whose characteristics reflect the way of life inherited from their ancestors. The belief applied by their ancestors can be clearly observed from the rituals performed when rice is planted and when it is harvested. Its application should be in accordance with the various requirements applied and applicable since the era when their ancestors lived. This indicates that the cultural pattern of the community is still strongly related to the belief adhered to by their ancestors. In its current development, especially during the period of fifteen years (starting from 1994 to 2009), the people living at Mekar Sari village used it as a means of expressing aesthetics 
to glorify God, Sang Ilahi Swt. Therefore, the ideology of Dodod, which was created in the sixteenth century, has developed in such a way that it has also functioned to strengthen the belief of the community living in Banten which is identical with the religious community of Islam. The mixture of the two ideologies has tended to be made balanced by the teachings included in the Holy Book Al-Qur'an, causing the current existence of Dodod really have specific characteristics. The differences in meaning provided by the performers, the community and the Moslem leaders at Mekar Wangi village are expected not to lead to the contact in which conflicts may occur. It is expected that such differences will mix harmoniously. The meaningfulness of belief and the religious meaningfulness of Dodod should be developed simultaneously.

The second finding is that, as a building-community characteristic process and as an attempt to keep the mixture of the two ideologies balanced, the people living at Mekar Wangi village, as the main supporting community of Dodod, have been able to show their self identity as a religious Moslem community, and their adaptability to develop it in the future. The deconstruction taking place in the performance of its new compositions, when it is performed for weeding ceremony and khitanan procession, serves as aesthetic expression which does not deconstruct various hierarchical binary oppositions of whether performing elements are used or not used, but serves to ascertain truth by making such oppositions more correlative. The creation of its new compositions has automatically caused the degree of its religiosity to shift from being performed for agricultural rituals to being performed as art containing Moslem nuisance. However, from what has been observed and analyzed, the realization and performance of its new compositions has not developed into being secular.

The third finding is that it will take a long time to be secular; even secularism will not occur to Dodod. The reason is that the meaningfulness provided is based on the teachings of Islam which contribute to self identity building. In addition, the teachings of Islam play important roles in highlighting religious pluralism and its followers. The meaningfulness of the religious level contained in Dodod, which is particularly provided by the leaders of pondok pesantren (Moslem boarding school), is the application of knowledge which is based on power used for doing something, as stated in the concept of relationship between knowledge and power which may lead to poststructruralism. Cultural studies are beyond religion, but the meaningfulness of Dodod, which is based on religion, is expected to be able expand the implications of the religion itself, making what is scientifically required in Al-Qur'an can be used as science which supports power.

Inheritance is necessarily done as an attempt to preserve Dodod from being extinct. The process of inheritance applied by its last heir is one of the proper attempts which needs to be continuously done in such a way that inheritance may be felt by all the villagers initiated by the children as one of the heirs which are assumed to be able to appreciate what has been done by their parents and ancestors when creating arts and culture. 


\section{CONCLUSIONS AND SUGGESTIONS}

\section{Conclusions}

From all the results of analysis, as far as the religious transformation of Dodod performed at Mekar Wangi Village is concerned, several conclusions can be withdrawn as follows.

The first conclusion is that Dodod is one of the traditional cultural inheritances which was born and has been developing at Mekar Wangi village, Saketi District, Pandeglang Regency, South Banten, Banten Province. It was predicted to be born in the sixteenth century, as a means of cultural rituals. It was performed in three stages such as tetanen, ngalaksa and rasulan. Tetanen is a ritual performed by the villagers when rice is planted in the rice fields. Ngalaksa is a ritual performed when the rice plant bears fruit and rasulan refers to a ritual when the rice is harvested and stored in what is termed as the rice barn (leuit).

The second conclusion is that the ideology on which the religiosity of Dodod was based when it was born and developing in the sixteenth century was the cult of the Goddess of Rice which was assumed to be able to maintain the fertility of the rice plant so that the farmers would obtain yield abundantly. Such a cult is part of the belief which is still influenced by the culture adhered to by the ancestors of the people living at Mekar Wangi village, which is known as Sunda Wiwitan tradition. During the transformational process, especially since the people applied the Moslem values, the ideology, on which Dodod is based, has been much influenced by the belief in Islam. All the behaviors in its performance are based on the consideration whether what is done has been in accordance with Islam as the religion they have adhered to or not.

The Dodod performed at Mekar Wangi village is basically a cultural activity which is based on two ideologies such as the cult and the performance. As a cult, it is performed using many offerings, many items and the magic formula taken from the poem of Lutung Kasarung which is considered sacred by the villagers. It is performed as a mediation or spiritual contact between them and supernatural strengths such as the souls of their ancestors and Sang Hyang Dewi Nyi Pohaci (Dewi Sri). Nowadays the realizations of the aesthetic expressions contained in its performance are integrated in every wedding and khitanan ceremonies. In addition, it has been an art which is full of religious values of Islam, the reflection of the people living at Mekar Wangi village.

The next conclusion, which is the third, is that during the transformational process (from pre-modern into modern community), Dodod has been influenced by the culture coming from outside Mekar Wangi village. The interactive and sustainable process between its performers and their socio-culture outside them has been responsible for such a cultural contact. This has also led to an ideological contact, shift in aspects of role and function, form and performance structure and the meaning contained in it. However, such an ideological contact has not led to any conflict but to a shift in ideological basis from the cult of Dewi Padi (the Goddess of Rice) to a one which refers to the values of Islam and as a result, its new compositions have been created. The shift in role and function can be observed from the fact that it has only been performed for rasulan ritual. Currently the interpretation contained in the 
rasulan ritual is directed to the form of communication to Allah Swt, God, the Creator. It is performed to welcome the bride and the bridegroom in the wedding ceremony, as a procession in khitanan ritual and as amusement or a show for public.

The fourth conclusion is that Dodod has been currently inherited and will be inherited formally and informally. The informal inheritance means the inheritance which is done from generation to generation, that is, the one which is based on family relationship among the performers and the musicians. The informal inheritance has been done through performing participation and imitation. The formal inheritance has been done from primary school, junior high school and senior high school. Dodod has been used as the learning material of arts and culture; a term used to express awareness that culture should be systematically inherited and expressed. What is meant is that the behavior and instruments created by the ancestors or predecessors of the people living at Mekar Wangi village should be inherited to the next generation systematically.

The fifth, which is the last conclusion, is that the current religious values of Dodod in the life of the Mekar Wangi villagers, after Islam was introduced, has shifted to those which are based on Islam. The meaningfulness is focused on the intactness of movements, the costumes worn, the meaning of the poem of Lutung Kasarung, the meaning of the magic formula and its existence as the art and culture of Islam. This will make its new compositions survive for a long time (in the postmodern area) as it contains the religious values of Islam supported by the Moslem leaders (Kiyai). Such meaningfulness is the application of knowledge and power, which, although initially it leads to a conflict, is acceptable to all the performers and community. Such an attempt should be followed with dialogues among various community components such as Majelis Ulama Indonesia and Dinas Kesenian so that arts and culture will never get extinct.

\section{Suggestions}

Based on what has been concluded above, several suggestions are provided as follows.

The first suggestion is that the basic policies which are necessarily applied by the last heirs, as far as the process of enculturation of Dodod is concerned, to the primary school students are as follows:

(a) Its standard structure of movements should be maintained and referred to in the structure of movements which have been modified. The faith expressed based the teachings of Islam, as suggested by the leaders of pondok pesantren (Moslem boarding school), may be integrated with aesthetic values of the traditional Moslem people living at Mekar Sari village so that it may be inherited formally at schools.

(b) The structure of movements and all the supporting aspects of Dodod are necessarily selected before creating new compositions which will be inherited to the students so that their religiosity will not be vague. The existence of its new compositions still treats its original form as the cultural treasure which needs preserving.

The second suggestion, which is the fourth, is that the Moslem leaders especially the leaders of pondok pesantren (Moslem boarding school) should treat Dodod as the 
culture of the people living at Mekar Wangi village, which can be made to be the culture which is in accordance with the values of Islam. This is made possible by supporting the existence of its new compositions created by it last heirs, and by treating its original form as the treasure of the national culture.

The next suggestion, is that the related governmental institutions, especially the Department of Education and Culture, may accept the new findings in the form of learning material or model of arts and culture, which carries the cultural treasure of Banten community especially Mekar Sari village. By adopting Dodod as the learning material at formal or informal schools, the students' insight into the attempts made to preserve the only art and culture which was born and has been developing at their home village. The influence of acculturation in its many aspects are not to be treated as exterminating religiosity but may be assumed as its universal realization.

\section{DAFTAR PUSTAKA}

Agus, Bustanuddin

2006 Agama Dalam Kehidupan Manusia. Pengantar Antropologi Agama. Jakarta: Grafindo.

Ahimsa, Putra., Heddy Shri

2001 Strukturalisme Levi-Strauss Mitos dan Karya Sastra. Yogyakarta: Galang Press.

Aiken., D. Henry

2002 Abad Ideologi. Jogyakarta: Yayasan Bentang Budaya.
Al-Qaardhawi, Yussuf

1998 Islam Bicara Seni. Alih Bahasa Wahid Ahmadi. Solo: Intermedia.

2000 Islam dan Seni. Alih Bahasa Zuhairi Misrawi. Bandung: Pustaka Hidayat.

Barker, Chris

2005 Cultur Studies. Teori dan Praktik. Terjemahan Cultural Studies: Theory and Practice. Yogyakarta: Bentang (PT. Bentang Pustaka).

Dibia, I Wayan .et.al

2006 Tari Komunal. Buku Pelajaran Kesenian Nusantara. Jakarta: Lembaga Pendidikan Seni Nusantara.

Djajadiningrat, Hosein.

1983 Tinjauan Kritis Tentang Sejarah Banten. Sumbangan Bagi Pengenalan Sifat-Sifat Penulisan Sejarah Jawa. Jakarta: Djambatan.

Ekadjati, Edi. S

1985 Kebudayaan Sunda (Suatu Pendekatan Sejarah). Jakarta: Pustaka Jaya.

Gulliot, Claude

1990 The Sultanate of Banten. Jakarta: Gramedia Book Publishing Division.

Hasbullah

2001 "Islam dan Transformasi Kebudayaan Melayu Riau (Integrasi Islam Dalam Kebudayaan Melayu di Siak Sri Indrapura Propinsi Riau)". (Tesis). Bandung: Program Pascasarjana UNPAD. 
Iskandar, Yoseph

2001 Sejarah Banten. Dari Masa Nirleka (Prasejarah) hingga Akhir Masa Kejayaan Kesultanan Banten (abad ke-17). Jakarta: Tryana Sjam'un Corp.

Kasmahidayat, Yuliawan

2002 "Individualisme dan Kolektivisme Masyarakat Petani di Banten Selatan (Studi Interaksi Simbolik dari Upacara Rasulan di Desa Mekar Wangi, Banten Selatan)". (Tesis). Bandung: Program Pascasarjana UNPAD.

2011 Agama Dalam Transformasi Budaya Nusantara. Bandung: Bintang Warli Artika.

Lubis, Nina .H

2003 Banten Dalam Pergumulan Sejarah (Sultan, Ulama,Jawara). Jakarta: Pustaka LP3S Indonesia.

Sumardjo, Jakob

2006 Khazanah Pantun Sunda Sebuah Interpretasi. Bandung: Kelir.

Turmudzi, H.M. Didi

2002 “Transformasi Budaya Pasundan Melalui Sistem Persekolahan di SMU Pasundan". Disertasi. Bandung: Pascasarjana UNPAD.

Yahya Omar,H.M. Toha

1983 Hukum Seni Musik, Seni Suara dan Seni Tari dalam Islam. Jakarta: Widjaya. 